\title{
Cluster Model of Regional Tourist Business in Russia
}

\author{
Tatyana Evgen'evna Karmanova ${ }^{1}$, Elena Nikolajevna Podsevalova ${ }^{1}$, Shakhlo Sobirovna Zikirova ${ }^{1}$, Anna \\ Alexandrovna Silaeva ${ }^{1} \&$ Valentina Petrovna Leonova ${ }^{1}$ \\ ${ }^{1}$ Russian State University of Tourism and Service, Cherkisovo settlement, Pushkinsky district, Moscow Region, \\ Russian Federation \\ Correspondence: Tatyana Evgen'evna Karmanova, Russian State University of Tourism and Service, Glavnaya \\ St., 99, Cherkisovo settlement, 141221, Pushkinsky district, Moscow Region, Russian Federation. E-mail: \\ karmanova_tanya@mail.ru
}

\author{
Received: November 21, 2014 Accepted: December 18, $2014 \quad$ Online Published: February 25, 2015 \\ doi:10.5539/ass.v11n6p279 \\ URL: http://dx.doi.org/10.5539/ass.v11n6p279
}

\begin{abstract}
Regions of Russia have huge climatic and historical-cultural potential, needing an effective use. A prerequisite for this is the development of tourism as a system of tourism enterprises and related industries. This system is a so-called tourist cluster-a group of businesses on a limited geographical area; these businesses directly or indirectly related to the tourism industry, provided a high level of infrastructure development and service, and have established social and political relations.
\end{abstract}

Keywords: the tourism cluster, the cluster approach, the development of tourism in the regions, cluster business

\section{Introduction}

Tourism is one of the directions of development of economy in post-industrial society, enabling to solve a wide range of important socio-economic problems. These include problem solving enhanced reproduction of labor resources, increase employment, increase well-being and improve the quality of life of the society, ensuring social and cultural development of the population (Karmanova et al., 2012).

The tourism industry combines not only a large number of tourism enterprises, and enterprises related to tourism industries and indirectly involved in the provision of services of tourist character. Russia lags behind in the development of tourism from other countries: the share of tourism services in the gross domestic product of Russia is only about 1.5\%-306,4 billion rubles ( $\$ 11.3$ billion.), while in France-about 33.5 billion, Spain-36.7 billion dollars, and in the U.S.-80.7 billion dollars.

Russia has the most powerful natural-climatic, socio-economic, cultural and historical tourism resources. Based on them you can create a unique tourist industry that meets modern requirements, to create competitive tourism products and to successfully develop domestic tourism (Silaeva et al., 2014).

The underdevelopment of domestic tourism leads automatically to limit the possibility of receiving foreign guests. Accommodation facilities, tourist infrastructure are united for domestic and foreign tourists.

In recent years, Russia has taken a number of measures to attract foreign tourists. According to the Federal target program "Development of domestic and inbound tourism in the Russian Federation (2011-2018), approved by the Russian government in 2011, total funding for the Program for 2011-2018, at prices of corresponding years is 332 billion. The goal of this Program is to improve the competitiveness of the tourist market of the Russian Federation that meets the needs of Russian and foreign citizens in high-quality tourist services.

Tourist and recreational business in Russia can be competitive only if that would fundamentally change management system development in this sector. Need to replace outdated methods come modern control technology. This new modern control technology is the cluster approach.

\section{Methodology}

The necessity of studying clusters and cluster systems in the travel and recreational sector has led to the use of General scientific and special methods. To General scientific methods include: dialectical abstract-logical analysis, the method of expert estimations, dynamic and comparative analysis, synthesis, management decisions, comparison and generalization. 
Cluster theory has been studied by many prominent scientists, and, depending on the direction of research, they have different interpretations of the concept of cluster. The founder of the cluster approach in Economics is recognized as M. porter, which defines a cluster as "a group of geographically adjacent interconnected companies and associated organizations operating in a certain area, characterized by common activities and complementary". In tourism clusters are characterized by interrelated institutional objects in a limited area, which are engaged in activities related to tourism and recreation services (Porter, 2001).

Scientists impose different interpretations and additions to the concept of "cluster approach". There are about 20 definitions of the term "cluster" in the most famous works of foreign scientists. It seems to us that the concept of the cluster approach is broader and deeper than it is treated in the literature, and its purpose is not only innovation in the economy, but also the use of innovative technologies in the management system. From this point of view, the cluster approach is legitimate and appropriate in any multi-structure the business as a tool to enhance its overall competitiveness.

\section{Results}

\subsection{The Impact of Tourism on the Economy of the Region}

Tourism and recreation as one of the most profitable inter-complexes, in many developed countries play a significant role in the formation of gross domestic product, creating jobs, enhancing trade balance (Ketels et al., 2012).

The impact of tourism on the socio-economic situation in the region during the current economic crisis and after it is determined primarily by the multiplicative effect. The tourism industry is a leader among other sectors of the size of the multiplier effect on the economy. Investment in tourism infrastructure during the crisis is carried out at relatively low prices for construction services for the development of business plans, designing, low cost labor. At the same time the tourism development increases employment in construction related industries (production of construction materials, design etc.). The conditions for retraining and the creation of an adequate supply of qualified personnel have to work in tourism after a crisis.

The direct impact of tourism on the economy of a country or region is the result of tourist expenditure for the purchase of goods and services of tourism. Spending tourists increase the income of the tourist region, which in turn leads to a chain of expenditure-revenue-expenditure", and so on up until these relationships are not completing the chain. Thus, the effect of initial income due to tourism expenditure is difficult to overestimate, as related to subsequent cycles of tourist spending. Besides the direct impact of tourist spending on the development of the region there is also an indirect effect, or "multiplier effect" ("multiplier" from lat. multiplicator-multiplying), which shall enter into force as circulation tourism expenditure in the region (Shepelev et al., 2012).

The income of the region is the taxes received from this revenue and leave at the disposal of the region. The money tourists begin to work entirely on the region's economy, when a tourist company buys local goods and services. Sellers of these goods and services received money from the tourists of them pay wages to their employees, which, in turn, spend it on the purchase of goods, payments for services and etc., However, if employees receiving salary, spend it on the purchase of imported goods or vacation abroad, then there is leakage of funds from the region. The combination of direct and indirect effects of the scheme expenses of tourists determines the impact on the local economy as a whole. Usually not all the income received in each cycle of tourist spending is spent. Some part of it is deposited, and the other is spent outside the region. The ability to retain a hike within the region depends on the economic isolation of the region and the reliance of the local economy. If the local economy is able to produce goods and services that are in demand among tourists, the multiplier effect will be very significant. The more goods imported from other regions, the smaller the multiplier effect.

To achieve a similar effect you can use one of the forms of economic integration-the cluster formation.

The creation of clusters, due to the General laws of development of the economy at the present stage is the development of partnerships between the state, economy and science.

\subsection{Measures Taken by the Government to Enhance the Competitiveness of the Tourism Business}

Measures taken by the Government of the Russian Federation for foreign tourists have yielded results in recent years there has been continued growth in the number of visited Russia foreign tourists. In 2012 this figure rose to 2.57 million, which is $10 \%$ higher compared with the same period in 2011 , last year thanks to the successful holding of the Year of Russian tourism in China, the number of visited Russia Chinese tourists increased by $46 \%$, reaching 343 thousand people. In 2012, the number sent to the RF tourists China ranked second in the world. 
According to the Federal service of state statistics (Rosstat), the most frequently Russia in 2012 was visited by the tourists from Germany-375,28 thousand (8.3\% more than in 2011), USA-179,76 thousand (an increase of $5.9 \%$ ), the UK-135,94 thousand (an increase of 5.8\%), Finland-120,30 thousand (down 10\%), Italy-118,72 thousand (down 5\%) and Turkey 100,91 thousand (an increase of 25\%).

It should be noted that compared with other travel powers, Russia is visited by so many foreign tourists. For example, in 2012, France was attended by more than 80 million tourists, in this regard; France has maintained its first place in the list of the world's most popular destinations for travel. For the title of most popular tourist country with France is not the first year competing U.S. and China in 2011 in the U.S. nearly 60 million tourists in China-more than 55 million.

In 2013 in the ranking of the attractive tourist destinations as Russia fell by four points to 63 seats, which is comparable with the level in 2011, the Share of tourism in GDP is far below the global average in 2011 this figure amounted to only $6.5 \%$, which is $3 \%$ less than the world average.

A number of experts' tourist business in Russia insists that the increase in the number of foreign visitors constrains only the difficulty of obtaining a Russian visa. The Russian Union of tourist industry has long campaigned for the introduction of a simplified visa regime for foreign tourists, passengers of cruise ships and ferries. According to experts, any simplification of visa formalities increases the number of tourists up to $30 \%$ per year.

However, according to experts, the tourist attractiveness of the Russian Federation also reduces the number of other factors. In the Federal Agency of the Federal tourism Agency believes that Russia remains for foreigners dear country, the quality of services is not always at the proper level, there is a problem with the number of hotels tourist class, which should offer more affordable prices for entry operators and good Commission. Another important disadvantage of reducing the attractiveness of Russia for foreign tourists, are expensive tickets (Kryukova et al., 2013).

\subsection{The Stagnation of the Tourism Industry: Causes and Ways to Overcome by Using the Cluster Management Model}

So, causes a significant permanent increase in the cost of tourist services in Russia are:

- poor infrastructure: insufficient number of hotels, lodges and other means of collective tourist accommodation;

- monopoly in the transport sector and annual growth rates for rail and air tickets;

- specialized in the development and understanding of the role of the tourism industry: not used reserves for the development of such types of tourism as a scientific, business, educational, medical, cultural, educational;

- poor use of the natural potential of all regions of Russia, first of all, the territory of Siberia.

We must understand that only the uniqueness of the natural resources and rich cultural heritage cannot be the only and sufficient condition to ensure the successful development of tourism in the country, as they represent only one element of the tourist potential (Kryukova et al., 2014).

In today's global economy, the state tourism largely depends on the development of the most competitive tourist consolidations based on the use of cultural-historic and natural resources and related infrastructure, professional staff, educational and scientific institutions, extensive entertainment and etc.

The desired results can be achieved by improving and diversifying the existing tourism products, development of promising new types of tourism, the quantitative and qualitative development of tourism clusters (Kryukova et al., 2014).

Tourist and recreational cluster is created with the aim of improving competitiveness of individual enterprises, but also in the whole region, due to the synergies, including: stimulating innovation, new business directions. Thus, the creation of tourist and recreational cluster enhances socio-economic development of the region.

Cluster business is a joint development of the companies, the joint territory, infrastructure, human resources and other characteristics, which allows the best way to optimize the production process and better allocate funds for the development (Porter, 2003).

Benefits from the cooperation of firms that provide tourism services that enable the efficient use of collective possibility of creation of tourist services and contribute to the development of enterprises which are not related directly to this area (Kryukova et al., 2014). The creation of tourist cluster leads to diversification and specialization of production, reconstruction of the shared infrastructure, and provides an opportunity to benefit 
from the emergence of the ability to discuss complex issues in close contact with the suppliers about the availability of the necessary components).

In addition to the above advantages, cooperative networks contribute to the development of new models of production process and organization, exchange of technical and other market information, agreements for the purchase and sale of goods and services, establishing an overall marketing company. Interaction and synergy that result from the joint action has a distinct advantage over isolated operating companies.

\subsection{Tourism Cluster: Definition, Nature, Composition}

The configuration of the tourist cluster is a (Sölvell \& Williams, 2013):

- complex of tourist resources, attracting non-indigenous inhabitants of the territory;

- the concentration of companies designed to meet the tourist demand: restaurants, sector placement, transportation, crafts and travel agencies etc.;

- sector and industry, aimed at supporting tourist services;

- environmentally friendly and cheap infrastructure (roads, fuel, sewage, medical care);

- companies and institutions that provide the necessary qualified personnel, information support and financial capital;

- internal Agency, organizing and implementing the cluster concept;

- government bodies regulating and coordinating patterns that affect cluster formation.

The proposed understanding of the tourism cluster is a manifestation of a systemic approach to organization of tourist activity is very close to the definition of resort and tourist complex.

Tourist clusters are formed based tourism assets in the region and consist of enterprises in various sectors related to service tourists, for example, tour operators, hotels, public catering, souvenir producers, transport companies and other (Podsevalova et al., 2011).

The main difference of the tourist cluster from the resort and tourist complex lies in the innovative nature of the activities of the cluster, as well as in enhancing the competitiveness of enterprises in the tourism cluster, and, as a consequence of the development of the entire region.

Members of the regional tourist cluster included interacting entities in the tourism sector, paired activities, controls and coordination, public organizations, scientific institutes. Functional structure of regional tourism cluster includes the institutional environment, an innovative environment and the production environment of the tourist product. The functioning of the regional tourist cluster is in collaboration with the environmental, socio-cultural, economic and institutional environment. The structure of the regional tourist cluster in different regions of different components is depending on the combination of territorial recreational resources, prerequisites concentration of tourist enterprises of various specializations.

Tourism clusters of various specializations there are several ways of development (Kutsenko et al., 2011). Some fall, others become larger and grow. In conditions of high competition tourism clusters tend to co-operate in joint complementary activities, as well as partnerships with other industry clusters. This process is characterized by the formation of a regional tourist cluster, which is determined by the presence of geographical, economic, social and infrastructural characteristics.

The formation of a coordinating body within the cluster phenomenon is optional, but in terms of national continuity of economic policy, it should be noted that this step is important not only for territorial development, but also for the business people themselves, because one of the most important functions of the body-providing dialogue between stakeholders, educational and research centers, investors and entrepreneurs in related industries.

Specialization of regional tourism cluster is directly related to the sources and resources of its formation and composition of its participants. Regional tourist cluster is formed by the merger of the local tourism clusters in its territory (Kostryukova et al., 2011). The emergence of such clusters is influenced by the following factors and conditions:

Resource factors (natural, cultural, historical, human, financial and land resources, infrastructure)-potential for development of specific types of tourism specialisation cluster, provide the specifics of complementary enterprises (agro-tourism cluster, health cluster, water-sports cluster and others). 
Activity factors (created as a result of human activity)-ensure the competitiveness of tourist activity due to the conditions created and implemented it on this site.

These include technological know-how in tourism, specific knowledge, skills and crafts, causing the specialization area. Moreover, the area may not have the resource factors, the cluster can be created based on the activity factors.

The process of formation and development of regional tourism cluster slows limiting factors: economic, institutional, geographic, and social infrastructure. Identification of limiting factors contributes to the prediction of the formation and development of regional tourism cluster, helps to choose relevant (in accordance with the specifics of the region) the position of the authorities during cluster formation (conducting, non-interference, creation of necessary conditions).

\subsection{Advantages and Prospects of Cluster Business}

Consideration of tourism based on the cluster concept allows us to offer new methods of zoning destination (tourist destination). Cluster approach to tourism development has two aspects: territorial and sectoral. Tourism can be considered as a natural catalyst for the development of the territory. Uncontrolled, unorganized tourism has negative effects: deals damage to the environment, leads to the destruction of cultural and historical heritage, becomes a threat to the potential of tourism development in the territory.

At the same time tourism is a source of income, contributing to the formation of new jobs, the development of the area, stimulating the development of social and environmental infrastructure (Kaurova et al., 2014). There is a relationship between sustainable development economic, socio-cultural, natural, institutional subsystems and sustainable development of tourism, which includes elements of all these subsystems. If sustainable tourism development is observed prevalence of positive impact on the natural, socio-economic environment is over the negative. For example, the area also is a resource that provides additional competitive advantages for the tourism enterprise.

The implementation of cluster policy promotes growth business competitiveness through the implementation of effective interaction potential members of the cluster associated with their geographically closest location, including increased access to innovation, technology, know-how, specialized services and qualified personnel, as well as reducing transaction costs, ensuring the creation of preconditions for the implementation of joint cooperation projects and productive competition.

The results of the implementation of cluster policy is productivity growth and innovation activity of enterprises in the cluster, as well as increasing the intensity of development of small and medium enterprises, promotion of direct investment, ensuring rapid socio-economic development of regions based clusters.

\section{Discussion}

\subsection{The Implementation of Cluster Policy in the Regions of Russia}

To date, the use of the cluster approach has already taken one of the key strategies of socio-economic development of a number of subjects of the Russian Federation and municipal formations. A number of projects for the development of regional clusters are implemented in the initiative order (Kryukova et al., 2013). At the Federal level, formed a number of mechanisms to provide flexible funding for cluster development.

Thus, in accordance with the Rules for the provision of the Federal budget funds provided for state support of small business, approved by the decree of the Government of the Russian Federation dated 22 April 2005 \# 249, on a competitive basis, the provision of subsidies to the subjects of the Russian Federation for financing of the measures provided for in the appropriate regional program. This mechanism creates opportunities for flexible use of financial support of subjects of the Russian Federation in order to implement a wide range of cluster projects (Kryukova \& Makeeva, 2013).

Opportunities for the development of cluster projects opens the potential of special economic zone of technical innovation, industrial, recreational and port types that are generated in accordance with The Federal law "On special economic zones" dated July 22, 2005 \#116-FL, as well as parks, the creation of which is carried out in the framework of implementation of the state program "Creation in the Russian Federation of technical parks in the sphere of high technologies" approved by the decree of the government of the Russian Federation dated March 10, 2006 \# 328-p.

In addition, effective mechanisms of financing development projects of the clusters formed as a result of the formation and activity of a number of development institutions, including the Investment Fund of the Russian Federation, the state Corporation "Bank for development and foreign economic Affairs (Vnesheconombank)", 
PC "Russian venture company", the Fund of assistance to development of small forms of enterprises in the scientific-technical sphere (Zaernjuk et al., 2014).

At the same time, the stage of practical implementation has reached only a relatively small part of projects cluster development. In a number of priority directions of cluster policy work has not yet started:

- not established mechanisms methodical, consulting and educational support cluster development;

- lack of necessary coordination of activities of Federal Executive bodies, Executive bodies of subjects of the Russian Federation and bodies of local self-government, associations of entrepreneurs in the implementation of the cluster policy;

- limited set of instruments of financial support for cluster projects from budgetary sources.

It is necessary to increase the capacity utilization of cluster development as one of the priorities of competitiveness and diversification of the economy.

\subsection{Risks Arising from the Management of the Tourism Cluster}

However, the cluster model management in tourism business accompanied by risks that you should consider when creating a cluster. One of the main risks of the implementation of the cluster policy should include:

- the risks of choosing the wrong priorities funding of cluster policy from budgetary sources;

- the risk of inadequate coordination in the implementation of cluster projects at the Federal, regional and local levels;

- low level of participation of Executive authorities of subjects of the Russian Federation and local self-government in the implementation of cluster projects;

- risk of ineffectiveness of monitoring the implementation of the cluster policy, due to the lack of a clear system of indicators to measure their effectiveness.

The main directions of action aimed at preventing the risks of ineffective implementation of the cluster policy can be:

1) Development of clear criteria for assessing the efficiency and effectiveness of cluster projects, events and cluster policy in General.

2) Using the project approach and results orientation when providing financing.

3) The use of competitive and competitive mechanisms to support cluster projects.

4) The use of public-private partnerships as necessary conditions for the financing of the cluster projects.

5) The use of co-financing of the cluster projects implemented by the Executive authorities of subjects of the Russian Federation, on the part of municipalities and business.

6) Organization of special education programs for employees of public institutions in cluster policy.

7) The effective use of best international experience.

8) The flexibility of the used support mechanisms of cluster projects.

\subsection{Tourism Is a Sector That Is Prone to the Formation of Clusters}

The procedure for creating a cluster has two conditions. First, it must involve representatives of Federal, regional and local authorities, which, with their interests in the course of development of territories, wield (legal, financial, administrative) to influence the situation in the region. Secondly, the process of working on the creation of clusters in the region must be connected to the public in the face of the representatives of enterprises, communities, NGOs, etc.

In tourist activity in the cluster can be connected travel agencies, tour operators, hotels and other infrastructure. Companies within a cluster in this market are aimed at cooperation.

In addition to enterprises and institutions cluster includes a variety of resources-human, financial, natural incentives (e.g. tax incentives). Necessary components of the cluster are the physical infrastructure (e.g. roads), information and scientific-technical infrastructure. Thus, clusters are a group of related enterprises, concentrated in one geographic region within the same industry, aimed at meeting the demand in the industry, eliminating direct competition among the participants, in fact, serving different segments.

You can select a number of industry characteristics, determining the sphere of tourism as a cluster forming: 
The tourism industry is closely linked to other sectors of the economy: industry, agriculture, construction, trade, insurance, services (accommodation, catering);

From the above it follows that the participants of the tourist market belong to different sectors and interests of the owners of the companies often contradict each other;

The product of the tourism industry is a service that has the following characteristics: intangibility, failure to store, the variability of quality and inseparability from the manufacturer, a direct connection between the process of production and consumption. Thus, the consumer is a direct participant in the production process.

The above factors determine the particular importance of appearance and development of tourism clusters. They help each party to understand themselves as part of a whole, as an entity cluster revealed through the relationship of its constituent firms, which appear in the form of value chains and systems of value accumulation. To achieve competitive advantage, a firm must optimize both its own value chain and external chain connecting her with suppliers and consumers. Dynamic cluster encompasses many different value chains, the combination of which M. porter called accumulation system value ("value system"-a system of values) (Abashkin et al., 2012).

In Russia there is a list of 25 innovative territorial clusters (approved by the Government of the Russian Federation (order of August 28, 2012 \# DM-P8-5060). Directions of development of these clusters can be considered the most sophisticated. The predictive value of total revenue for the 25 selected clusters in 2016 will be 3810,6 billion rubles in prices of 2011-an increase of 105\% compared to 2011 (Abashkin et al., 2013).

Dynamics of production on the territory of the pilot clusters with more than 1.8 times exceeds the indicator of the dynamics of industrial production as a whole on the territory of the Russian Federation for the specified period, which, according to forecasts of the Ministry of economic development, is $58 \%$ at current prices.

Currently you have already created and will continue to create tourist and recreational cluster, in accordance with the Concept of long-term socio-economic development of the Russian Federation for the period till 2020. This is, for example, Arkhangelsk travel Association, tourism cluster in the Vologda region (130 travel agencies, 103 of, 40-50 catering; souvenir manufacturers, transport companies in the entertainment industry, only employs about 900 thousand people), tourism and recreation cluster in the Republic of Dagestan (approximately 12 thousand people), tourism and recreation cluster in the Republic of Kalmykia, the tourism cluster in the Volgograd region (consisting of more than 33 companies), recreation cluster in Kabardino-Balkaria. It is planned the creation of tourism clusters in the Republic of Tyva, Khakassia, Altai region, Tyumen oblast, Sverdlovsk oblast, Kamchatka, in the Republic of Mari El, in the Astrakhan region, etc. When creating these clusters are mostly used public investments (on average 60-70\%).

\section{Conclusion}

In the world today as one of the most effective control technology regional development is considered cluster-oriented policy.

The implementation of cluster policy involves ensuring effective interaction of Federal Executive bodies, Executive bodies of subjects of the Russian Federation and bodies of local self-government, associations of entrepreneurs.

Functions to ensure the initiation of the development strategies of clusters, to facilitate their organizational development and the principal amount of financial support cluster initiatives must be implemented by the Executive authorities of subjects of the Russian Federation and bodies of local self-government.

In the development of strategies for the development of clusters, carried out at the regional and municipal levels, should be provided with effective and appropriate priorities for the development of clusters in the framework of the regional and municipal strategies and programs of socio-economic development, including projects for the development of transport and engineering infrastructure, housing construction, and implementation of measures in support of small and medium enterprises, innovation and technology policy, educational policy, investment, policy, export promotion, development of industries.

This should create the prerequisites for effective use of financial mechanisms to support the implementation of the cluster policy provided from the Federal budget.

In this regard, the main directions of cluster policy at the Federal level will be the improvement of financial mechanisms to support the development of clusters, as well as providing the necessary methodological, consulting and educational support to their development. 


\section{References}

Abashkin, C. L., Goland, Y. M., Gokhberg, L. M., Kutsenko, E. C., Rudnick, P. B., \& Shadrin, A. E. (2013). Pilot innovative territorial clusters in the Russian Federation. In L. M. Gokhberg, \& A. E. Shadrin (Eds.), Under the General editorship. M.: Publishing house of the HIGHER school of Economics.

Abashkin, C. L., Oppression, A. D., \& Kutsenko, E. C. (2012). Cluster policy in Russia: From theory to practice foresight, 6(3), 16-27.

Karmanova, I. E., Kaurova, O. C., \& Maloletko, A. N. (2012). Statistics tourism. Tourism statistics: A textbook (p. 208). Moscow: KNORUS.

Kaurova, O. V., Kryukova, E. M., Maloletko, A. N., Deryabina, A. V., \& Yumanova, O. S. (2014). Modern trends in development of tourism statistics in the world and in Russia. Life Sci. J., 11(4), 451-454. Retrieved from http://www.lifesciencesite.com

Ketels, C., Lindqvist, G., \& Sölvell, Ö. (2012). Strengthening Clusters and Competitiveness in Europe. The Role of Cluster Organisations. The Cluster Observatory.

Kostryukov, O. N., \& Karpov, E. G. (2011). Methods for the identification of tourism clusters in the system of regional tourism. Problems of modern economy, 4(40).

Kryukova, E. M., \& Makeeva, D. R. (2013). Analysis of World and Russian Best Practices of Strategic Development of Mono-Towns. World Applied Sciences Journal, 27(Education, Law, Economics, Language and Communication), 167-171.

Kryukova, E. M., Makeeva, D. R., Atamanova, M. A., \& Shadskaja, I. G. (2013). Financial mechanism of housing and utilities infrastructure. Life Science Journal, 10(4), 25. Retrieved from http://www.lifesciencesite.com/lsj/life1004/099_21206life1004_790_794.pdf

Kryukova, E. M., Novikova, N. G., Zikirova, S. S., \& Podsevalova, E. N. (2014). Financial support of the formation of social housing in Russia and Abroad. World Applied Sciences Journal, 30(12), 1746-1748.

Kryukova, E. M., Razumovskiy, S. L., \& Vetrova, E. A. (2013). Mono-Town in the System of Economic Notions of the Russian Federation. World Applied Sciences Journal, 27(Education, Law, Economics, Language and Communication), 162-166.

Kutsenko, E. C., \& Tyumentseva, D. S. (2011). Clusters and innovation in the regions: Results of an empirical study. Questions of economy, (9), 93-107.

Mihajlovna, K. E., \& Pavlovna, S. A. (2014). Assessment of Efficiency of the Hotel Management by a Russian Company. World Applied Sciences Journal, 30(Management, Economics, Technology \& Tourism), 51-54.

Mihajlovna, K. E., Rafikovna, M. D., \& Konovalov, E. E. (2014). Tourism as Preferred Direction in the Strategy of Substitution of Industry Branches in Mono-Territories of Russian Federation. World Applied Sciences Journal, 30(Management, Economics, Technology \& Tourism), 176-178.

Podsevalova, E. N., Zikirova, W. C., \& Karmanova, T. E. (2011). Theoretical and methodological aspects of the organization of accounting and auditing at the enterprises of the tourism industry in terms of bankruptcy: Monograph (p. 133).

Porter M. Competitive. TRANS. from English. (2001). Home "Wilms" (p. 495). M.: Publishing House.

Porter, M. (2003). The Economic Performance of Regions. Regional Studies, 37(6\&7), 549-578.

Shepelev, I., \& Markov, Y. A. (2012). Tourist and recreational cluster-innovative mechanism of improvement of the system of strategic management of regional development. Modern research of social problems (electronic journal), 3(11).

Silaeva, A. A., Atamanova, M. A., \& Chkhikvadze, N. A. (2014). Development of resort and tourist potential as a promising avenue of socio-economic growth in Russia. Life Science Journal, 11(12s), 126-130. Retrieved from http://www.lifesciencesite.com/lsj/life1112s/023_26225life1112s14_126_130.pdf

Sölvell, Ö., \& Williams, M. (2013). Building the Cluster Commons. An Evaluation of 12 Cluster Organizations in Sweden: 2005-2012. Ivory Tower Publishers, Sweden.

Zaernjuk, V. M., Kryukova, E. M., Bokareva, E. V., \& Chernikova, L. I. (2014). A study of the theoretical approaches to the banking financial intermediation and its development trends. World Applied Sciences Journal, 30(12), 1723-1725.

\section{Copyrights}

Copyright for this article is retained by the author(s), with first publication rights granted to the journal.

This is an open-access article distributed under the terms and conditions of the Creative Commons Attribution license (http://creativecommons.org/licenses/by/3.0/). 